\title{
ART
}

\section{ФОРМУВАННЯ СТИЛІСТИКИ АРТИСТИЗМУ У САМОДІЯЛЬНОМУ ОРКЕСТРОВОМУ ВИКОНАВСТВІ УКРАЇНИ}

\author{
Аспірант Ірина Смірнова \\ Украйна, Суми, Сумський державний педагогічний \\ університет імені А. С. Макаренка
}

DOI: https://doi.org/10.31435/rsglobal_ws/30042019/6483

\section{ARTICLE INFO}

Received: 18 February 2019

Accepted: 24 April 2019

Published: 30 April 2019

\section{KEYWORDS}

artistry,

amateur performance,

orchestral performance,

amateurism,

collective music.

\begin{abstract}
In the article by I. Smirnova, the problem of the formation of the style of artistry in the amateur orchestral performance of Ukraine and the functioning of orchestral collectives in the conditions of the formation of artistic amateur activities and in the educational work in Ukraine of the 20 th and 3 rd years of the 20th century is considered. The urgency of the work is due to the fact that the specificity of the formation of amateur orchestral performance in the Ukrainian musical culture of this period is not sufficiently studied, although it played a prominent role in the further development of domestic amateur collective music. The object of attention was the enlightenment movement in Ukraine in the first half of the twentieth century - one of the brightest phenomena of cultural life of that period.
\end{abstract}

Citation: Ірина Смірнова. (2019) Formuvannia Stylystyky Artystyzmu u Samodiialnomu Orkestrovomu Vykonavstvi Ukrainy. World Science. 4(44), Vol.3. doi: 10.31435/rsglobal_ws/30042019/6483

Copyright: (C) 2019 Iрина Смірнова. This is an open-access article distributed under the terms of the Creative Commons Attribution License (CC BY). The use, distribution or reproduction in other forums is permitted, provided the original author(s) or licensor are credited and that the original publication in this journal is cited, in accordance with accepted academic practice. No use, distribution or reproduction is permitted which does not comply with these terms.

Вступ. Однією з помітних тенденцій сучасного українського мистецтвознавства $є$ постійне розширення дослідницького простору, в контекст якого включаються нові проблеми, з'ясування яких вкрай важливе для подальшого розкриття потенціалу мистецької науки. В цьому контексті, в дослідницький простір все активніше входить проблема артистизму у сучасних музичних напрямах, генетично пов'язаних з розважальною сферою, тобто, масовою культурою.

Результати дослідження. Крім концертної діяльності професійних та самодіяльних музичних колективів, були поширені нові форми масової музичної роботи - періодичні музичні виставки, які знайомили відвідувачів з досягненнями української радянської музичної культури. Першу подібну виставку під назвою «7 років музичної культури на Україні» було відкрито в Києві. На виставці, яка тривала з 20 листопада по 8 грудня 1924 року, було експоновано нотні видання, музичні інструменти радянського виробництва, діаграми розвитку музичних самодіяльних гуртків i мережі музичних учбових закладів. Також протягом 13 вечорів на виставці виступали доповідачі та відбувалися концерти самодіяльних і професійних хорів, оркестрів, ансамблів, солістів. Такі виставки стали невід'ємною частиною усіх масових музичних свят.

Одним із засобів контролю стали щорічні огляди самодіяльних гуртків. В Харкові, 3 1919 по 1934 рік столиці України, в 1927 році відбувся конкурс на кращого виконавця серед аматорів - гармоністів та міський огляд хорів, духових і народних оркестрів. Початок 30-х років характеризується піднесенням добробуту і культурного рівня життя трудящих України, здобутими на основі соціалістичної індустріалізації, успішного виконання першого п'ятирічного плану, ліквідації куркульства як класу на базі колективізації сільського 
господарства. В цьому надзвичайно складному процесі державної, громадської і політичної перебудови постала потреба концентрації всіх мистецьких ресурсів республіки для як найповнішого використання їх з агітаційною метою. Для практичного здійснення мистецьких завдань розроблялись і розсилались на місця репертуарні й методичні матеріали, відряджались інструктивні бригади для допомоги художній самодіяльності. Локальні огляди в Києві, Харкові, Полтаві, Одесі, стали своєрідною перевіркою стану музичної самодіяльності окремих районів. Вони довели можливість такої перевірки в усій республіці.

Значний розквіт музичної самодіяльності та нових засад артистизму виконавців підготував грунт для організації огляду музичного мистецтва - Всеукраїнської музичної олімпіади. Музичне бюро розпочало підготовку до наступного перегляду самодіяльних музичних гуртків у 1930 році і проходила під гаслом : «Музику - на фронт соціалістичного будівництва!», «Музику - на боротьбу за вугіль, метал і транспорт!», «Музику - на боротьбу за 3 -й вирішальний рік п'ятирічки!» та під знаком мобілізації всіх засобів музичної самодіяльності на виконання цих закликів. Було організовано робітничі бригади для обстеження художньої самодіяльності культурних закладів. Головним підсумком перегляду стало рішення Всеукраїнської ради профспілок провести перевірку всього музичного процесу в Україні. Основне завдання полягало в перевірці стану музичної самодіяльності міст і сіл, запровадження нового актуального за тематикою репертуару, активізації мистецтва, зокрема музично - хорової самодіяльності.

Для поповнення репертуару учасників Всеукраїнської музичної олімпіади було оголошено конкурс на створення масових пісень, хорів, кантат, творів для оркестрів, духових, народних інструментів і ансамблів бандуристів. Слід зазначити, що серед конкурсних творів для духових оркестрів на олімпіаді прозвучали: «Перша перемога» Г. Дранека, «Марш Дніпровського полку» П. Козицького, марш «Комсомолець», «Масовий танець», «Урочистий марш» Б. Лятошинського, «Урочистий марш» В. Смекаліна. Обов’язковим для всіх духових оркестрів було виконання маршу П. Садівничого на тему української народної пісні «По той бік гора». За умовами конкурсу твори мали відобразити боротьбу за соціалістичну перебудову народного господарства, за індустріалізацію країни, колективізацію сільського господарства, за виконання промфінплану, ударництво, новий соціалістичний побут. За умовами олімпіади іiі учасники, крім показу повноцінного репертуару і майстерності виконання, мали прийти до Всеукраїнського огляду з високими показниками масової музичної роботи в робітничих $\mathrm{i}$ колгоспних клубах, на виробництві і у військових частинах. Ці показники враховувалися журі при остаточній оцінки виступів. Високий виконавський рівень кращих вітчизняних самодіяльних оркестрових колективів сприяв їх визнанню за межами України. В наслідок першої загальноміської музично-хорової Олімпіади ініціатори організаційної п'ятірки вийшли з ініціативою проводити і надалі вже за певним планом і методикою масові музично-хорові заходи. 3 їх ініціативи в листопаді 1927 року була скликана нарада 3 метою налагодження та поліпшення масової музичної роботи по клубах, школах, сільських будинках та інших організаціях. Наприкінці 1928 року Музичне бюро провело організаційну роботу по підготовці та проведенню 2- ї Музичної олімпіади. Завдяки діяльності Музичного бюро за рік значно збільшилась кількість учасників художньої самодіяльності. В 2-й Олімпіаді прийняли участь 2000 виконавців. Наприкінці Олімпіади виступили: об'єднаний хор (1000 виконавців, керівник - О. Брижаха), об'єднаний духовий оркестр (600 виконавців, керівник - П. Леонтьєв), об'єднаний оркестр народних інструментів (400 виконавців, керівник - В. Комаренко). Всі колективи показали неабияку злагодженість, дисциплінованість, розуміння творів, що виконувались. Під кінець виступив об'єднаний колектив під керівництвом композитора М. Вериківського, до якого увійшли всі учасники Олімпіади [1, с. 47]. В зазначений час в самодіяльних колективах була запроваджена учбово-виховна музична робота, яка в окремих випадках мала характер систематичного музичного навчання.

Для масової музичної освіти населення при Харківському музично-драматичному інституті організовуються загальнодоступні музичні курси. У Києві в 1928 році відкрилася робітнича консерваторія (ректор С. Тишкевич), такий же заклад був заснований в Харкові (його очолив О. Мартинсен). Нарада постановила створити при культвідділі ХОРПС'у Музичне бюро, яке вже у листопаді 1927 року розпочало свою роботу з обліку клубних музичних гуртків усіх типів та їх керівників. Вивчення стану музичної роботи було завершено організацією 
перегляду самодіяльної музичної роботи, що мав за мету відібрати кандидатів на участь в окружному конкурсі Харкова хорів та оркестрів. Конкурс було проведено протягом 1928 року в приміщенні Харківського державного драматичного театру. Участь в ньому взяли 12 хорів, 8 духових оркестрів. Народно-інструментальне оркестрове виконавство було представлено 6 оркестрами народних інструментів. Переможцем конкурсу став оркестр клубу «Червоний міліціонер» під керівництвом М. Калініна. Другу премію поділили між собою оркестр клубу ім. Ілліча (керівник М. Юзефович), та оркестр Л. Гайдамаки при клубі «Металіст». Конкурсним твором для всіх оркестрів був «Танець маленьких лебедів» 3 балету «Лебедине озеро» П. І. Чайковського в перекладі для народних інструментів В. А. Комаренка. В квітні 1932 року робітничий домрово-балалаєчний оркестр Миколаєва, на запрошення Всесоюзної Центральної Ради профспілок, виступав у Москві під час IX з'їзду профспілок. Ці періодичні видання піднімали і болючі питання, наприклад якості репертуару. Музична самодіяльність потребувала значно більше репертуару у потрібній жанровій різноманітності, але можливості видавництв були перевищені. Наслідком таких публікацій став наказ від травня 1938 року Наркому освіти України про організацію при всіх районах, міських і обласних бібліотеках відділів нотномузичної літератури. Преса піднімала питання і недостатності музичних інструментів, а також їх низької якості, яка заважала розвиткові інструментальної музики. 3 метою покращення якості інструментарію наприкінці 30 -х років відбулися: Перша Всесоюзна виставка народних інструментів; Перший Всесоюзний конкурс майстрів і майстерень на краще виготовлення домр і балалайок. На 30-ті роки припадає інтенсивний розвиток самодіяльного оперного мистецтва. Розвиваються і народжуються нові оперні студії при Будинку вчених, клуби поліграфістів, клуби робітників держторгівлі. В Харкові при Будинку вчителя існували великий самодіяльний оперний колектив та симфонічний оркестр під управлінням I. Михайленко. При Будинку вчених діяв великий симфонічний оркестр з наукової інтелігенції під управлінням Каца. В Одесі при клубі швейної фабрики відкрилась перша робітнича опера при якій існував симфонічний оркестр під керівництвом К. Домінчена. Аналіз процесу розвитку музичної самодіяльності 1920-1930-х років показав, що за цей час вона набула масового характеру, збагатилася такими новими формами масової музичної практики, як дні музики, музичні виставки тощо, які сприяли формуванню артистизму оркестрового самодіяльного i професійного виконавства.

Висновки. Аналіз формування артистизму у діяльності оркестрових колективів у самодіяльній галузі зазначеного часу дозволяє дійти певних висновків. Суб'єктивним чинником культивування оркестрового музикування в межах самодіяльного руху в Україні в $20-30$ роки XX століття була плідна професійна діяльність митців (Я. Полферов, П. Козицький, Г. Хоткевич, М. Радзієвський), що зумовило специфіку функціонування очолюваних ними колективів, а, через це, і всього напряму виконавства. Побутування на Україні самодіяльних колективів, а саме оркестрів (народних, духових, симфонічних) мало велике значення для поширення музичної культури серед трудящих. Слід відзначити їх у популяризації класичного надбання, бо твори цього напряму складали основний відсоток репертуару. Естетика самодіяльного оркестрового виконавства грунтувалася на дореволюційних просвітніх принципах, тобто оркестрове музикування вважалося і більшовицькою культурною політикою дійовим засобом музичної просвіти пролетаріату. 3 іншої сторони колективне оркестрове виконавство відбивало тогочасний політичний курс на «колективізацію». Значне поширення в художній самодіяльності отримали традиційні для дожовтневого просвітнього руху народноінструментальні та духові колективи. Чинниками їх популярності були: функціональність духових оркестрів, що виражалась в їх активному використанні підчас різноманітних мітингів та демонстрацій; придатність для таких складів революційного, здебільше маршового репертуару; широка популярність народних інструментів в першу чергу гармоніки та балалайки, які вважалися i пропагувалися як суто пролетарське музичне знаряддя; демократичність та нескладність у технічному засвоєнні репертуару для оркестрів народних інструментів, який складали здебільше ті ж революційні твори та елементарні обробки в основному на рівні гармонізації народної музики; епізодичність функціонування в художній самодіяльності симфонічних оркестрів пов'язана як із суто музичними (складність, у порівнянні з вдосконаленими народними та інструментами духового оркестру, технічного засвоєння струнно-смичкових та духових дерев'яних інструментів), так і 3 культурно- 
політичними чинниками: цей різновид оркестрів, особливо перше десятиліття української влади, вважався пережитком буржуазного минулого.

Еволюція репертуарної політики в самодіяльній оркестровій сфері 20-30-х років XX століття в Україні, характеризується еволюцією від революційних творів та елементарних обробок народних мелодій до активного звернення, до класичного репертуару цьому сприяла діяльність керівників органів у самодіяльній галузі( товариства ім. М. Леонтовича, ХОРПС) які очолювали просвітні діячі 3 дореволюційним досвідом (М. Вериківський, П. Козицький, М. Радзієвський, В. Комаренко). Діяльність провідних самодіяльних оркестрів народних інструментів мала значний вплив на формування вищої професійної освіти у народноінструментальному виконавстві академічного напряму: оркестр «МІК» - на специфіку початкової діяльності кафедри народних інструментів Київської консерваторії відкритої у 1928 році, Миколаївський самодіяльний оркестр народних інструментів - крім однозначного впливу на діяльність кафедри народних інструментів Одеської консерваторії, на створення в Миколаєві музичного училища.

\section{REFERENCES}

1. Гуменюк А. Українські народні музичні інструменти, інструментальні ансамблі та оркестри / А. Гуменюк. — К. : Радянська Україна, 1959. - 54 с.

2. Давидов М. Історія виконавства на народних інструментах / М. Давидов. - К. : НМАУ ім. П. І. Чайковського, 2005. - 419 с.

3. Имханицкий М. История исполнительства на русских народных инструментах / М. Имханицкий. М. : РАМ им. Гнесиных, 2002. - 351 с.

4. Історія української музики : В 6 т. Т.4 : 1971-1941. — К. : Наук. думка, 1992. — 614 с.

5. Лі Шуай. Джаз в українському музичному виконавстві початку ХХЇ століття.- авторєф. канд. дис. за спец. 17.00.03 - муз. мистецтво. - Суми, 2019. - 20 с.

6. Ольховський Ю. Нарис історії української музики / Ю. Ольховський. - К. : Музична Україна, 2003. $-512 \mathrm{c}$.

7. Понікарова Л. Харківська академічна школа народно-інструментального виконавства / Л. Понікарова. - Х. : ВД "ІНЖЕК”, 2005. — 76 с. 